\title{
Methodology of complex analysis for production costs at manufacturing enterprises
}

\section{Daiva Tamulevičienè}

Faculty of Economics and Business Administration,

Vilnius University,

Lithuania

daiva.tamuleviciene@evaf.vu.lt

\section{Manuela Tvaronavičienè}

Faculty of Business Management,

Vilnius Gediminas Tecbnical University,

Lithuania

manuela.tvaronaviciene@vgtu.lt

\author{
Jonas Mackevičius \\ Faculty of Economics and Business Administration, \\ Vilnius University, \\ Lithuania \\ jonas.mackevicius@evaf.vu.lt
}

Abstract. Production cost is one of the most important company's activity indicators characterizing company's expenditure related to production and sales. Under competitive market conditions it is important for managers to be aware of the actual production cost and of the possibilities to decrease it. It can be achieved by conducting complex analysis of the production cost. The aim of this article is to substantiate the significance of expenditures and production cost at manufacturing enterprises and to suggest a methodology of such a complex analysis of production cost for manufacturing enterprises. The article analyses the volumes, dynamics and structure of Lithuanian business enterprises' expenditures as well as the cost of sales by economic activity types. An exemplary scheme of the complex analysis of the production cost for manufacturing enterprises is presented. Actions carried out by production cost analysts are studied; absolute and relative indicators are estimated and analysed.

Keywords: production cost, cost analysis, complex analysis, expenditures of Lithuanian enterprises.

JEL Classification: D24, E23, L23 


\section{INTRODUCTION}

Production cost is one of the most important company's activity indicators characterizing company's expenditure relative to production and sales. Production cost plays a crucial role when forecasting prices, determining profit and profitability, drawing up budgets, controlling expenditures, assessing efficiency of a company and its departments, and for making the most of economic decisions as such. If companies want to survive in the competitive environments, they have to find ways to decrease their production costs to a minimum. Production cost is one of the most widely analysed economic indicators. If one looks into scientific studies on the accounting issues in any country, one would see that at least $50 \%$ of all scientific studies analyse costs (Valužis, 2000, p. 91). Most of foreign and Lithuanian authors have analysed various production cost aspects. Types of production costs according to the volumes of expenditures included into the production cost (workshop, manufacturing, full manufacturing, commercial or financial costs) and the cost estimation time (planned, normative, actual cost) have been already analysed in great deal of detail to date. In scientific publications, particular attention has been paid to the production cost calculation issues. Advantages and disadvantages of production cost calculation methods (job-order costing, process costing, standard costing, normative costing, absorption costing, direct costing, marginal costing, activity-based costing, target costing, life cycle costing, just-in-time costing, etc.) were analysed.

Production cost has not lost and will not lose any of its importance: it is closely linked to economic and financial activity of a company and to the indicators characterizing it (assets, equity, liabilities, revenue, expenses, etc.). Thus, every change in a company's economic and financial activities has its impact on production cost. Reduction of production cost is the main way to increase profit. Under current dynamic and competitive market conditions, it is very important to reveal the reserves and possibilities to reduce production cost. It can be done by carrying out complex analysis of production cost. Yet, scientific literature hardly contains any tips on how to carry out such an analysis. Scientific literature mostly focuses on the analysis of cost in general rather than production cost (Novak et al., 2017). The cost are often analysed from the perspective of management decision making, for instance, cost behaviour analysis, cost-volume-profit analysis, cost optimization analysis, etc. (Kidane, 2012; Novák \& Popesko, 2014; Firescu \& Branza, 2016; Ghandour, 2017; Budrionyte \& Gaižauskas, 2018; Lujal \& Iseni, 2018; Glembotskaya et al., 2020; Le et al., 2020, Panfilova et al., 2020 and others). Also, general recommendations on how to analyse the raw materials costs as well as labour costs, how to determine their variances, and how to carry out the production cost composition and structure analysis are presented (Wiener, 1962; Mackevičius, 2007; Żwirbla, 2009, 2010; Bragg, 2017; Gunarathe \& Samudagre, 2018; Petrenko et al., 2018; Stoenoiu \& Cristea, 2018; Bozgulova, et al., 2019; Aryasri, 2020 and others). Yet, no consistent or comprehensive (i.e. complex) production cost analysis methodology has been developed so far. Such an analysis is important for companies from all sectors, but particularly for manufacturing enterprises since the production cost calculation procedure is more comprehensive in these companies and more expenditure items are included into it. Respectively, production cost analysis is more complicated at manufacturing enterprises, thus, it is necessary to carry out such an analysis in the most consistent way.

The subject of the research is the production cost and its analysis methodology.

The aim of the study is to substantiate the significance of expenditures and production cost at manufacturing enterprises and to suggest a methodology for comprehensive analysis of production cost that may be applied by manufacturing enterprises. 


\section{PROCESS AND METHODOLOGY OF THE STUDY}

The complex analysis of the production cost was developed in three stages. During the first stage, the aim was to analyse the volumes, dynamics and structure of the Lithuanian business enterprises' expenditure as well as the cost of sales according to the economic activity types. Taking the fact that the production cost consists of various expenditure into account, it was important to substantiate the significance of the expenditure for Lithuanian business enterprises and distinguish those business sectors which incur the highest expenditure. For this purpose, the Lithuanian business enterprises' expenditure and expenses dynamics and structure analysis both according to the expenditure items, and to the economic activity types during the years 2014 to 2018 was carried out. Data from the Official Statistics Portal was used for the study.

The aim of the second stage was to prepare an exemplary scheme of the complex analysis of the production cost at manufacturing enterprises by indicating the most important stages of the analysis. In order to prepare the system, such methods as analysis of scientific literature and logical analysis were used. Thanks to the analysis of scientific literature the main principles on how to carry out the complex analysis were identified. Also, when carrying out this method, scientific studies with suggestions on how to conduct a complex analysis of concrete financial indicators, were introduced. Based on these studies and using the logical analysis method, a scheme for the complex analysis of the production cost for manufacturing enterprises was prepared. During the third stage, the actions carried out by analysts throughout the different stages of the complex analysis of the production cost were analysed. For this purpose, the information collection, classification, comparison and elaboration methods were employed.

\section{LITHUANIAN BUSINESS ENTERPRISES' EXPENDITURE, ITS DYNAMICS AND STRUCTURE}

The production cost-depending on the aims for the production cost calculation and analysis set out within the company-are comprised of various expenditure. Every company and every activity incurs expenditure of some kind (raw materials, fuel, labour, fixed assets depreciation and amortization, etc.). The expenditure is the highest during the manufacturing process: it is related to the manufacturing process technology and its development. A considerable part of expenditure goes to manufacturing preparation, management and servicing as well as improvement of working conditions, etc. It is important to determine and assess all expenditure and apply a precise system to estimate them. Company's managers and accountants are responsible for this. Only after timely and precisely determining the expenditure related to the production and after including it into accounting records, it is possible to calculate the actual cost of production and its separate types, to effectively control whether the expenditure is used for its intended purpose, whether it corresponds to the standards, and to look for possibilities to decrease it.

The expenditure incurred by a company influences not only the production cost volume-the company's financial state, its activity results, competitiveness in the market, and continuity of activity depends on it. Not only the management of the company but all of its employees should be aware of the information on expenditure, the points in which it is incurred and the factors influencing it. Every employee has to feel responsibility for the expenditure incurred because of their activity and try to decrease it. The society of the country is interested in the information on the expenditure as well. The significance of the expenditure and production cost is revealed when assessing the dynamics and structure of Lithuanian business enterprises expenditure. Summarized information on business enterprises' expenditure based on their financial and statistical reports is provided by the Statistics Lithuania annually. Fig. 1 presents the dynamics of the expenditure volume and the number of Lithuanian business enterprises during the years 2014-2018. 


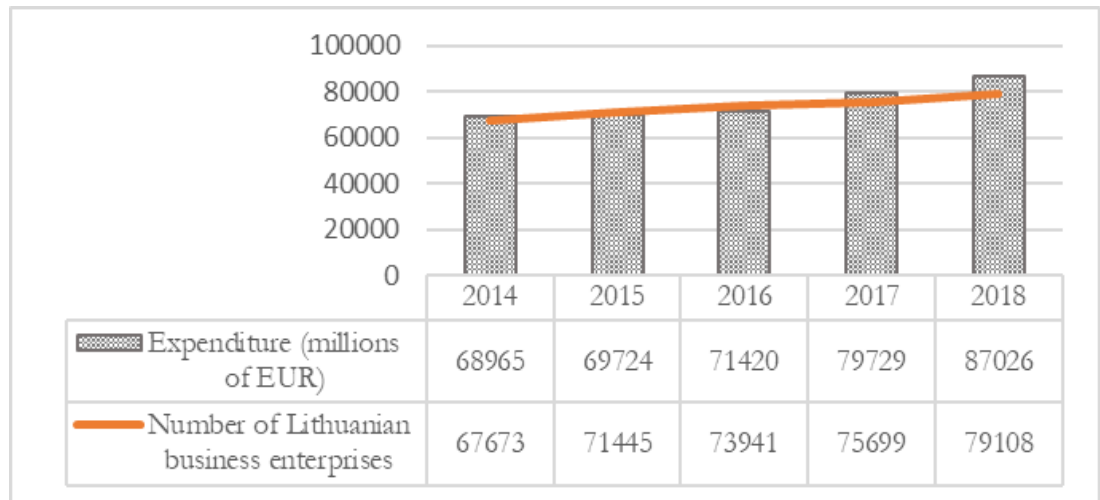

Figure 1. Dynamics of the number of Lithuanian business enterprises and their expenditure during the years 2014-2018

Source: compiled by the authors in accordance with the data of Official Statistics Portal

Figure 1 shows that in 2018 the Lithuanian business enterprises' expenditure amounted to nearly 87 billion euros and-compared to 2014-increased by $26.18 \%$. Yet, during the 2014-2018 period, the number of companies increased too, from 67,673 to 79,108 , i.e. by $16.90 \%$. However, the expenditure has been increasing faster than the number of companies in the recent years. The expenditure per company respectively increased and in 2018 amounted to 1.10 million euros. During the analysed period, this indicator was the lowest in 2016 ( 0.96 million euros).

Every company incurs expenditure attributable to a certain type of economic activity. Cost analysis according to the types of economic activities show that the highest expenditure was incurred in wholesale and retail trade as well as manufacturing enterprises: in 2018 the expenditure by these companies amounted to respectively 35.265 million euros and 20.908 million euros or $40.52 \%$ and $24.11 \%$ of all the expenditure incurred by business enterprises (see Table 1). The expenditures are relatively high in enterprises from transportation and storage as well as construction sectors: during the analysed period they amounted to respectively $11.11 \%$ and $6.27 \%$ of all the expenditure incurred by business enterprises.

Table 1

The structure of the expenditure according to the types of economic activities during the years 2014-2018

\begin{tabular}{|c|c|c|c|c|c|c|}
\hline \multirow{3}{*}{ Economic activity } & \multicolumn{6}{|c|}{ Expenditure } \\
\hline & \multicolumn{5}{|c|}{ percentage } & $\begin{array}{l}\text { millions } \\
\text { of EUR }\end{array}$ \\
\hline & 2014 & 2015 & 2016 & 2017 & 2018 & 2018 \\
\hline 1. Wholesale and retail trade & 41.13 & 42.38 & 42.94 & 41.92 & 40.52 & 35.265 \\
\hline 2. Manufacturing & 26.10 & 24.32 & 23.40 & 23.75 & 24.11 & 20.980 \\
\hline 3. Transportation and storage & 10.57 & 10.58 & 11.08 & 11.65 & 11.76 & 10.236 \\
\hline 4. Construction & 6.41 & 6.35 & 5.89 & 6.13 & 6.55 & 5.699 \\
\hline $\begin{array}{l}\text { 5. Electricity, gas, steam and air conditioning } \\
\text { supply }\end{array}$ & 3.60 & 3.16 & 2.91 & 2.59 & 2.98 & 2.590 \\
\hline 6. Information and communication & 2.17 & 2.40 & 2.60 & 2.55 & 2.72 & 2.368 \\
\hline 7. Administrative and support service activities & 1.97 & 2.24 & 2.38 & 2.42 & 2.52 & 2.192 \\
\hline 8. Professional, scientific and technical activities & 2.06 & 2.28 & 2.47 & 2.35 & 2.30 & 2.003 \\
\hline 9. Other activities & 5.99 & 6.29 & 6.33 & 6.64 & 6.54 & 5.693 \\
\hline Total & 100.00 & 100.00 & 100.00 & 100.00 & 100.00 & 87.026 \\
\hline
\end{tabular}

Source: compiled by the authors in accordance with the data of Official Statistics Portal

Companies carrying out the following types of economic activities incur the least expenditure: repair of computers and personal and household goods, other personal service activities; education; mining and 
quarrying; human health and social work activities, and others (included into the section Other activities). Every company's financial state, activity results and even activity continuity opportunities-regardless of the company's activity type-depend on the volume of the expenditure and changes in its structure. Therefore it is very important to calculate, control, classify and analyse the expenditure and to use the acquired data purposefully, in order to achieve specific company's goals.

Expenditure structure analysis shows (see Table 2) that the value of raw materials, materials, fuel, goods for resale consumed amount to the largest relative part of the total expenditure: in 2014 they amounted to $68.36 \%$ and in 2018 to $63.16 \%$. Value of services purchased and personnel costs have the second highest relative rate: in 2018 their expenditure amounted to respectively $19.38 \%$ and $13.72 \%$ within the total expenditure structure. The share of depreciation of tangible fixed assets and amortization of intangible fixed assets within the total expenditure structure was less significant.

Table 2

Expenditure structure 2014-2018 (\%)

\begin{tabular}{|l|c|c|c|c|c|}
\hline \multicolumn{1}{|c|}{ Indicator } & $\mathbf{2 0 1 4}$ & $\mathbf{2 0 1 5}$ & $\mathbf{2 0 1 6}$ & $\mathbf{2 0 1 7}$ & $\mathbf{2 0 1 8}$ \\
\hline $\begin{array}{l}\text { 1. Value of raw materials, materials, fuel, goods for resale } \\
\text { consumed }\end{array}$ & 68.36 & 66.32 & 64.24 & 64.99 & 63.16 \\
\hline 2. Value of services purchased & 16.36 & 17.42 & 18.36 & 17.88 & 19.38 \\
\hline 3. Personnel costs & 11.33 & 12.23 & 13.25 & 13.36 & 13.72 \\
\hline 4. Depreciation and amortization of fixed assets & 3.66 & 3.70 & 3.88 & 3.49 & 3.47 \\
\hline 5. Taxes on production & 0.29 & 0.33 & 0.27 & 0.28 & 0.27 \\
\hline Total & 100.00 & 100.00 & 100.00 & 100.00 & 100.00 \\
\hline
\end{tabular}

Source: compiled by the authors in accordance with the data of Official Statistics Portal

When assessing the main articles of Lithuanian business enterprises' expenditure in absolute terms, it is clear that during the analysed period they showed trends of increasing. Dynamics of such expenditure during the years 2014-2018 in billions of euros is provided in the Table 3.

Table 3

Expenditure on raw materials, services and personnel from 2014 to 2018 (billions of euros)

\begin{tabular}{|l|c|c|c|c|c|}
\hline \multicolumn{1}{|c|}{ Indicator } & $\mathbf{2 0 1 4}$ & $\mathbf{2 0 1 5}$ & $\mathbf{2 0 1 6}$ & $\mathbf{2 0 1 7}$ & $\mathbf{2 0 1 8}$ \\
\hline $\begin{array}{l}\text { 1. Value of raw materials, materials, fuel, goods for resale } \\
\text { consumed }\end{array}$ & $\mathbf{4 7 . 1 4}$ & $\mathbf{4 6 . 2 4}$ & $\mathbf{4 5 . 8 8}$ & 51.81 & 54.96 \\
\hline 1a) of which value of raw materials, materials and fuel & 19.38 & 17.95 & 16.57 & 18.95 & 20.38 \\
\hline 1b) of which value of goods for resale & 27.76 & 28.29 & 29.31 & 32.86 & 34.58 \\
\hline 2. Value of services purchased & 11.28 & 12.14 & 13.11 & 14.25 & 16.87 \\
\hline 3. Personnel costs & 7.81 & 8.53 & 9.47 & 10.65 & 11.94 \\
\hline Total & 66.23 & 66.91 & 68.46 & 76.71 & 83.77 \\
\hline
\end{tabular}

Source: compiled by the authors in accordance with the data of Official Statistics Portal

The Table 3 shows that in 2014 the expenditure on raw materials, services and personnel amounted to 66.23 billion euros whereas in 2018 it was equal to 83.77 billion euros: it increased by 17.54 billion euros or by $26.48 \%$. The expenditure on personnel grew the most rapidly: in 2014 they amounted to 7.81 billion euros, whereas in 2018 the number was 11.94 billion euros, i.e. It increased by $52.88 \%$. It is noteworthy that wage expenditure per one employed person increased as well: for example, in 2017 the wage expenditure per a relative employee (recalculated for a full-time employee) amounted to 13 thousand euros, whereas by 2018 the number increased to 14.3 thousand euros. In terms of types of economic activities, the manufacturing, wholesale and retail trade as well as transportation and storage companies incur the highest expenditure on personnel.

Yet, in terms of expenditure structure, the main expenditure item is Value of raw materials, materials, fuel, goods for resale consumed. In 2018, this type of expenditure amounted to 54.96 billion euros and- 
compared to 2013-increased by 3.7 billion euros or by $7.69 \%$. The share of value of raw materials, materials, and fuel is the largest in manufacturing companies. In 2018, the expenditure on raw materials and fuel in this sector amounted to 13.45 billion or $66.00 \%$ of all the expenditure on raw materials and fuel throughout all the country's business enterprises. Transportation and storage companies are in the second position $(10.63 \%)$ and construction companies in the third $(9.22 \%)$. Expenditure on goods for resale are the largest in wholesale and retail trade companies (82.97\%). Decreasing these types of expenditure is one of the most important tasks for every company seeking good activity results.

It is important to emphasize that each year Statistics Lithuania provides not only Lithuanian business enterprises' expenditure indicators regarding particular expenditure items and types of economic activities but also data on the expenses incurred by the companies. As the Table 4 shows, the cost of sales indicator is the most significant among all the expenses items. In 2018, the cost of sales amounted to 71.5 billion euros or $80.31 \%$ of all the expenses incurred by all the country's business enterprises. It is noteworthy that during the analysed period, the relative share of cost of sales-as with the other articles on expenses-changed only slightly. This shows that companies follow the principles of expenses structure and try to control both the operating expenses, and the financing and investment activity expenses.

Table 4

Companies' expenses and their structure dynamics in the years 2014-2018

\begin{tabular}{|c|c|c|c|c|c|c|}
\hline \multirow{3}{*}{ Expenses items } & \multicolumn{6}{|c|}{ Expenses } \\
\hline & \multicolumn{5}{|c|}{ percentage } & millions of euros \\
\hline & 2014 & 2015 & 2016 & 2017 & 2018 & 2018 \\
\hline 1. Cost of sales & 80.39 & 80.78 & 79.82 & 80.40 & 80.31 & 71.456 \\
\hline 2. Operating expenses & 16.74 & 17.40 & 18.60 & 17.95 & 17.89 & 15.918 \\
\hline $\begin{array}{l}\text { 3. Financing and investment } \\
\text { activity expenses }\end{array}$ & 1.42 & 1.30 & 1.16 & 1.18 & 1.18 & 1.051 \\
\hline 4. Other activity expenses & 1.45 & 0.52 & 0.42 & 0.47 & 0.62 & 547 \\
\hline Total: & 100.00 & 100.00 & 100.00 & 100.00 & 100.00 & 88.972 \\
\hline
\end{tabular}

Source: compiled by the authors in accordance with the data of Official Statistics Portal

Also, a cost of sales analysis by the types of economic activity is carried out (see Table 5). Wholesale and retail trade companies incur the highest cost of sales expenses: In 2018, they amounted to 30.38 billion euros or $42.51 \%$ of all the costs of sales incurred by all the country's business enterprises. They are followed by manufacturing, transportation and storage as well as construction companies whose cost of sales, when put together, amounted to nearly 31 billion euros or $43.29 \%$ of the total cost of sales.

The structural and dynamical analysis of Lithuanian business enterprises' expenditure and expenses from 2014 to 2018 revealed that the major share of expenditures incurred by Lithuanian business enterprises consists of value of raw materials, materials, fuel, goods for resale, value of services purchased and personnel costs. Assessment based on the types of economic activity shows that these expenditures are the highest (except for value of goods for resale consumed) in the manufacturing enterprises. In 2018, the expenditure on raw materials, materials and fuel incurred by the manufacturing enterprises amounted to 13.45 billion or $66.00 \%$ of all the expenditure on raw materials, materials, and fuel throughout all the country's business enterprises. Value of services purchased, and personnel costs was the highest at the manufacturing enterprises as well. In 2018 it amounted 5.72 billion or 19.05\% of all the value of services purchased and personnel costs throughout all the country's business enterprises. 
Structure of cost of sales by the types of economic activities during the years 2014-2018

\begin{tabular}{|c|c|c|c|c|c|c|}
\hline \multirow{3}{*}{ Economic activity } & \multicolumn{6}{|c|}{ Cost of sales } \\
\hline & \multicolumn{5}{|c|}{ percentage } & \multirow{2}{*}{$\begin{array}{c}\begin{array}{c}\text { millions } \\
\text { of euros }\end{array} \\
2018 \\
\end{array}$} \\
\hline & 2014 & 2015 & 2016 & 2017 & 2018 & \\
\hline 1. Wholesale and retail trade & 42.78 & 44.44 & 45.33 & 44.20 & 42.51 & 30.378 \\
\hline 2. Manufacturing & 27.43 & 25.40 & 24.38 & 24.65 & 25.08 & 17.921 \\
\hline 3. Transportation and storage & 10.65 & 10.72 & 11.14 & 11.55 & 11.87 & 8.479 \\
\hline 4. Construction & 6.50 & 6.28 & 5.67 & 5.95 & 6.34 & 4.530 \\
\hline $\begin{array}{l}\text { 5. Electricity, gas, steam and air } \\
\text { conditioning supply }\end{array}$ & 3.34 & 3.03 & 2.89 & 2.53 & 3.13 & 2.238 \\
\hline $\begin{array}{l}\text { 6. Administrative and support service } \\
\text { activities }\end{array}$ & 1.60 & 1.90 & 2.09 & 2.23 & 2.33 & 1.668 \\
\hline 7. Information and communication & 1.65 & 1.67 & 1.71 & 1.97 & 2.00 & 1.430 \\
\hline $\begin{array}{l}\text { 8. Professional, scientific and technical } \\
\text { activities }\end{array}$ & 1.42 & 1.61 & 1.73 & 1.56 & 1.60 & 1.142 \\
\hline 9. Other activities & 4.63 & 4.95 & 5.06 & 5.36 & 5.14 & 3.670 \\
\hline Total & 100.00 & 100.00 & 100.00 & 100.00 & 100.00 & 71.456 \\
\hline
\end{tabular}

Source: compiled by the authors in accordance with the data of Official Statistics Portal

In general, in 2018, value of raw materials, materials and fuel (except for value of goods for resale consumed), value of services purchased, and personnel costs amounted to $38.98 \%$ of all the country's business enterprises' expenditures. It is an incredibly significant share considering that the manufacturing enterprises amount only to $9.19 \%$ of all the business enterprises. From the analysis of the cost of sales according to the types of economic activity, it is clear that in absolute terms these expenses were the highest at wholesale and retail trade enterprises. Yet, from the assessment based on the cost of sales per one enterprise, this indicator is much higher at manufacturing enterprises. In 2018, the average cost of sales per one wholesale and retail trade enterprise amounted to 1.40 million of euros whereas at manufacturing enterprises this indicator was 2.47 million of euros $-76 \%$ higher. The results of this analysis show that manufacturing enterprises must pay the most attention to the analysis and assessment of expenditures since various expenditures are incurred during the production and they are larger than that of enterprises from other sectors; also the procedures to estimate the production cost are more complex. Respectively, the production cost analysis is more complicated in manufacturing enterprises thus it is necessary to carry it out in a consistent and comprehensive way.

\section{EXEMPLARY SCHEME OF THE COMPLEX ANALYSIS OF THE PRODUCTION COST}

A complex analysis is a harmonized system of indicators revealing all (or most of) the aspects of economic processes and providing summarized conclusions on the company's activity results. Inter-related indicators are selected rather than random ones for the analysis ant later they are compared with the company's planned, normative, and past indicators as well as with the respective indicators from other companies. Other bases of comparison are also possible. Theoretical issues on the complex analysis of a company's activity were studied in the works by Sheremet (2002), Savitskaya (2005), Kovalev (2004), Bocharov (2005); Mackevičius (2007); Hilkevics, \& Semakina (2019); Mazzoni (2020); Eddelani et al. (2019).

Theoretical foundations of the complex analysis were created by A.Sheremet. He distinguished three main stages of the complex analysis: 1) a preliminary review of the summarizing indicators; 2) a comprehensive in-depth analysis of all the indicators according to their groups; 3) a complex assessment 
summarizing companies' activity effectiveness (Sheremet, 2002, p. 147). He also identified inter-relations of the main company's activity indicators. A. Sheremet suggested to include eleven groups of financial indicators into the complex analysis which would encompass various company's activity areas, for example, production sales analysis, salaries analysis, profit and profitability analysis, assets profitability analysis, etc. The production cost analysis is distinguished as a separate component of the complex analysis. It is important to emphasize that the methodology on how to carry out the complex analysis of specific groups of financial indicators is already being analysed. The following studies on the methodologies of the complex analysis of financial indicators are noteworthy: complex analysis of net profitability of shareholders' equity (Mackevičius, Molienė \& Poškaite, 2007); complex analysis of gross profitability of sales (Mackevičius, Molienė \& Poškaité, 2008); complex analysis of inventories (Mackevičius \& Valkauskas, 2012); complex analysis of profitability of fixed tangible assets (Mackevičius, Subačienė \& Senkus, 2012), complex analysis of profitability (Tamulevičienè, 2016); complex analysis of bankruptcy forecasting (Mackevičius, Šneidere \& Tamulevičienè, 2018); complex analysis of tangible fixed assets (Tamulevičiene \& Mackevičius, 2019). However, the methodology on how to carry out the complex analysis of the production cost has not yet been analysed.

The main aim of the complex analysis of the production cost is to analyse all the elements of the production cost and determine the reserves and possibilities to reduce it. The information received from this analysis helps managers to answer the question they are concerned about: should they produce or purchase a certain product. In order to make the right decision, not only the production cost has to be estimated as precisely as possible but it also has to be compared with the price of the product in the market. If the cost difference is at the production disadvantage, the product should be purchased, and vice-versa, if the production cost is low, then the production may be sold profitably or a part of it may be left in the company for its purposes and needs. During the complex analysis of the production cost, the analysis of cost composition, structure and its changes during a certain period of time is carried out, all direct and indirect cost items are studied, possibilities to decrease certain costs are sought, various absolute and relative indicators are calculated.

The complex analysis of the production cost has to be carried out consistently, in certain stages. Only a precise production cost study can reveal the cost reduction reserves. It is suggested to analyse the production cost of every company consistently, as shown below (Fig. 2).

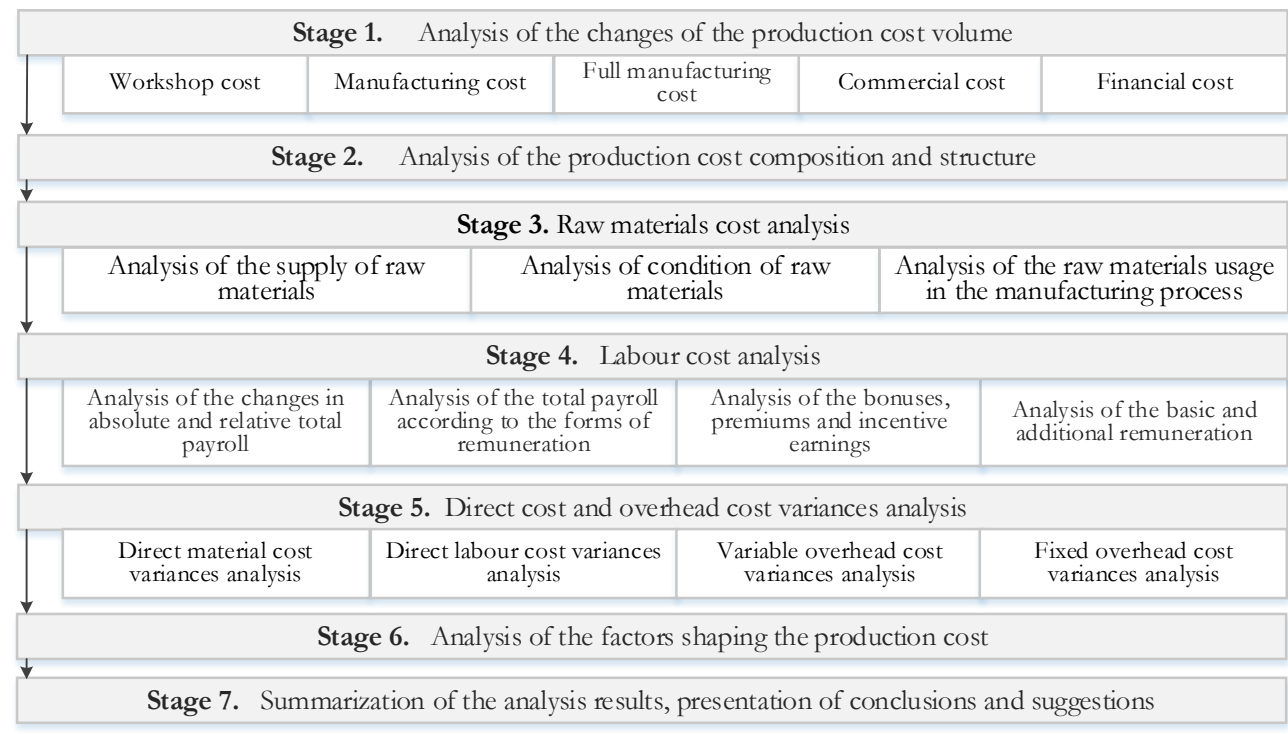

Figure 2. Methodology of the complex analysis of the production cost

Source: compiled by the authors 
The information received from the complex analysis of the production cost can be used not only to decide whether to produce or to purchase a product but for other purposes as well: to forecast prices, to evaluate the activity of the company and its branches, to draw up budgets, to make most of the economic decisions.

The following information sources are used to conduct the complex analysis of the production cost: income statement; planned, normative and reporting calculations on specific products; records in the Raw materials and components, Work in progress, Finished products and other ledger accounts; various information sources not related to accounting. The results of the analysis may be depicted in analytical tables and various diagrams.

\section{STAGES OF THE COMPLEX ANALYSIS OF THE PRODUCTION COST AND ACTIONS TAKEN DURING THEM}

As the Figure 2 shows, it is suggested to carry out the complex analysis of the production cost in 7 stages which are inter-related and supplement one another with information necessary for the next stage.

In the first stage of the production cost analysis, it is necessary to compare the cost of the reporting period with the cost of the previous period and determine the size and causes for its increase or decrease. It is appropriate to compare the production cost of all types, yet the main focus should be on the analysis of the manufacturing cost. This type of cost stands out because its estimation procedures are harmonized with the provisions of the Lithuanian 9th business accounting standard Inventories (2018) therefore not only management but financial accounting experts can assess manufacturing cost changes and their causes.

The second stage of the production cost analysis is the analysis of the cost composition and structure. This stage is aimed at finding out which types of costs are included into the production cost and which are not; which cost elements are attributable to the direct cost and which ones to the indirect cost; also, to evaluate whether certain cost were attributed to direct or indirect cost correctly. Then it is appropriate to estimate the share of direct and indirect cost and their separate items in the total production cost. A precise analysis of the cost composition and structure helps to determine how the production cost was shaped during a certain period and to find out which costs may be reduced.

The third stage is aimed at conducting the raw materials cost analysis. As the results of the Lithuanian business enterprises costs structure analysis during the years 2014 to 2018 revealed, these costs amount to a significant share within the total cost structure in Lithuanian manufacturing enterprises. The same trend has been observed in manufacturing enterprises of other countries. The studies show that in Western countries' manufacturing enterprises, the raw materials costs on average amount to 35-40\% of all costs and constitutes the main share of the production cost (Acién, et al., 2012; Wilting \& Hanemaaijer, 2014; Timmer, 2012, Petrenko et al., 2018).

It is appropriate to start the raw materials cost analysis from the assessment of the supply of raw materials. During this assessment it is determined whether the amount of raw materials is sufficient to ensure a normal manufacturing process. For this purpose-based on the actual amount of raw materials and daily consumption rate-actual number of days for which there are sufficient raw materials is estimated which is then compared to the set standards.

The supply of raw materials and amount of their inventories significantly depends not only on the scope of the manufacturing programme, the features of the technological processes, and manufacturing capacities, but on the managers' business development strategy and tactics as well. In some cases it may be useful to stock large amounts of certain raw materials, for instance, to prepare for supply disruptions, possible price rise in the future or to have a possibility to gain profit, i.e. to sell the previously purchased raw materials for a higher price. However if the company stocks up too much raw materials, it risks suffering 
significant losses as well: the stocked raw materials may decay, loose their qualitative properties, their storage and maintenance costs may increase, etc. Therefore, when conducting the supply of raw materials analysis, it is important to determine, whether the company has: 1) a prepared raw materials management system whose application would clearly show when, how much and what raw materials have to be ordered; 2) a set procedure on how to account for and control raw materials stored in warehouses and other departments of the company.

Equally important is to examine the condition of raw materials in order to determine whether they are not decayed and meet quality standards. It is possible to know whether stocks have not been moved for a while (which likely means that their quality is low) from the warehouse accounting data. If some raw materials were not transferred from the warehouse to the production line for more than a year and there are still large amounts of the stocks left, they are either unnecessary or they do not meet quality requirements.

Afterwards, the analysis of the raw materials usage in the manufacturing process is carried out. It is appropriate to conduct this analysis in two directions: 1) to analyse the total value of all the raw materials used; 2) to analyse the usage of certain raw materials. When carrying out the analysis of all the raw materials used in the manufacturing process, first of all, it is necessary to determine the precise value of all the used raw materials and compare it with the planned value. It is also important to estimate and assess relative indicators showing the efficiency of the usage of all raw materials (see Table 6).

Table 6

Raw materials usage efficiency indicators

\begin{tabular}{|l|c|l|}
\hline $\begin{array}{l}\text { Name of the } \\
\text { indicator }\end{array}$ & Calculation of the indicator & \multicolumn{1}{c|}{ Significance of the indicator } \\
\hline $\begin{array}{l}\text { Raw materials } \\
\text { receptivity } \\
\text { ratio }\end{array}$ & $\begin{array}{c}\text { Value of raw materials } \\
\text { consumed }\end{array}$ & $\begin{array}{l}\text { This indicator shows how many raw materials were } \\
\text { allocated per one euro worth of production; the higher } \\
\text { this indicator is, the more raw materials have to be used } \\
\text { for production }\end{array}$ \\
\hline $\begin{array}{l}\text { Raw materials } \\
\text { productivity } \\
\text { ratio }\end{array}$ & $\begin{array}{c}\text { Finished production } \\
\text { Value of raw materials } \\
\text { consumed }\end{array}$ & $\begin{array}{l}\text { This indicator shows the value of the production per } \\
\text { one euro worth of used raw materials; the higher this } \\
\text { indicator is, the fewer raw materials are used for } \\
\text { production }\end{array}$ \\
\hline $\begin{array}{l}\text { Raw materials } \\
\text { put in a good } \\
\text { use ratio }\end{array}$ & $\begin{array}{c}\text { Value of raw materials } \\
\text { put in good use }\end{array}$ & $\begin{array}{l}\text { The indicator shows how efficiently were raw materials } \\
\text { used, whether not too many of them were put to waste; } \\
\text { on the basis of this indicator, it is possible to make } \\
\text { assumptions on the company's resource saving policies }\end{array}$ \\
\cline { 2 - 3 } $\begin{array}{l}\text { Value of all raw materials used materials } \\
\text { storage time } \\
\text { (in days) }\end{array}$ & $\begin{array}{l}\text { Value of raw materials stored } \\
\text { Average value of raw materials } \\
\text { transferred to the production } \\
\text { daily }\end{array}$ & $\begin{array}{l}\text { This indicator shows how many days the raw materials } \\
\text { were stored in the warehouse; on the basis of this } \\
\text { indicator, it is possible to make assumptions on the } \\
\text { intensity and cyclical nature of the manufacturing } \\
\text { process, equipment load, raw materials storage } \\
\text { condition, etc. }\end{array}$ \\
\hline
\end{tabular}

Second direction of the analysis of the raw materials used is the analysis of specific raw materials used for certain production. It is important to identify how efficiently specific raw materials are used. For every raw material a usage rate must be set; it should then be compared with the amount actually used and determine whether the raw material was used more efficiently than the rate or not. Such a comparison may show what share of certain raw material was included into the product and was efficiently used in its production and what share was wasted.

In the fourth stage, the labour cost analysis is carried out. Firstly, the elements constituting the total payroll are studied: 1) the basic remuneration (estimated based on the time system, the piece rate system or the 
mixed system); 2) bonuses (for qualification); 3) premiums (for overtime, hazardous working conditions, involuntary breaks); 4) incentive earnings (annual, quarterly, occasional, etc.); 5) compensated absences (annual leave, additional leave, sick leave days); 6) mandatory contributions to the social security fund.

Later, absolute and relative changes in the total payroll are estimated. Absolute payroll savings or surplus are estimated as the difference between the actual and planned total payroll. Changes in the absolute total payroll indicator are influenced by the changes in the number of employees and the changes in average annual salary of an employee. These two factors also have an impact on the changes of the relative total payroll indicator. However, besides these two factors, the relative savings or surplus are additionally influenced by the changes in production plan implementation and the value of the adjustment ratio. Table 7 shows formulae to calculate the factors influencing the changes in the total payroll.

Table 7

Factors influencing absolute and relative total payroll savings or surplus

\begin{tabular}{|l|l|}
\hline \multicolumn{1}{|c|}{ Factor } & \multicolumn{1}{|c|}{ Formula to calculate the influence of the factor } \\
\hline $\begin{array}{l}\text { Influence of the changes in the number } \\
\text { of employees }\end{array}$ & $\begin{array}{l}\text { (Actual average number of employees }- \text { Planned average number of } \\
\text { employees) } \times \text { Average annual salary of an employee }\end{array}$ \\
\hline $\begin{array}{l}\text { Influence of the changes in the average } \\
\text { annual salary of an employee }\end{array}$ & $\begin{array}{l}\text { (Actual average annual salary of an employee }- \text { Planned average } \\
\text { annual salary of an employee }) \times \text { Actual average number of employees }\end{array}$ \\
\hline $\begin{array}{l}\text { Influence of the changes in production } \\
\text { plan implementation and the value of } \\
\text { the adjustment ratio }\end{array}$ & $\begin{array}{l}\text { (Planned total payroll } \times \text { Changes in production plan implementation } \\
\text { in } \% \times \text { Adjustment ratio) } / 100\end{array}$ \\
\hline
\end{tabular}

It is of crucial importance to carry out the analysis of the total payroll according to the forms and varieties of remuneration. The analysis is used to determine what type of remuneration is the main one in the company, whether its application is methodically substantiated, i.e. whether it is selected taking the amount of work, its quality, contents, conditions, and other factors into account. Later, it is determined whether the remuneration for the employees according to the selected form of remuneration was calculated correctly. An analyst has to be aware of the forms of remuneration and the procedure of their application in practice. In practice, various varieties of piece rate or time forms of remuneration are applied. When analysing, it is important to find out, whether the application procedure for these varieties is being followed.

When analysing the remuneration calculation according to the piece rate form, it is important to check, whether the hourly rates are set correctly and on what criteria they are based. Then it has to be checked if the employee's salary directly depends more on the production amount in a certain period of time or on the work done. Also, it is important to check, whether the piece rate is appropriate. The practice shows that it is more appropriate to apply it in the cases when the individual output can be calculated and when the work is systematically repeated and precisely regulated.

When studying the time system of remuneration, not only the correctness of the remuneration calculation is checked, but also the appropriateness of the application of this form of remuneration is determined. Also, this helps to find out for which jobs it is appropriate to apply the time system of remuneration. As the practice shows, it is the most appropriate to apply this practice to those jobs, whose operational contents and consistency are often changing and where it is impossible to precisely determine the output by individual employees. It is important to determine whether the company's hourly rates were methodologically substantiated.

Special focus must be paid to various bonuses, premiums and incentive earnings which often amount to a large part of the total payroll. The nature of bonuses and premiums is varies significantly; for instance, they are granted for qualification, knowledge of languages, IT skills, hazardous working conditions, overtime, work during night-time, etc. After working conditions change, for example, if the equipment breaks down, the workplace is changed or the necessary raw materials are not supplied, certain premiums 
are often paid out as well. Various premiums for the planned tasks implementation, good annual results, good quality of work, work efficiency, etc. may be paid out too. It is very important to analyse the reasons for which the bonuses, premiums and incentive earnings were paid out, how often they were paid out and what impact did this have on the efficiency of work, reduction of the production cost, improvement of the production quality. It is important to identify, if the bonuses, premiums and incentive earnings were allocated rightly and estimated precisely.

Also, it is recommended to conduct the analysis of the types of the total payroll which are basic and additional remuneration. When analysing, it must be checked whether the labour costs are included into the basic or additional remuneration according to their purpose; to determine if the documents correctly note the piece rates or the tariff rates and whether the output is estimated correctly. Also, it must be checked, whether the source documents are correctly formalized, whether the titles of hourly rates and operations match, whether all the variances are sufficiently paid for.

The fifth stage of the production cost analysis is aimed at calculating the actual direct materials cost and direct labour cost variances from the standard cost as well as determination of factors influencing them. Also, if there is a need, the overhead cost variances analysis may be carried out. Comparison of actual cost and standard cost to determine variances and the factors influencing them is one of the most effective ways to reduce cost and to reveal specific cost reduction reserves. After receiving the information on variances, the management is able to control certain economic operations, assess the factors shaping the value of the direct materials costs, direct labour costs and overhead costs.

One of the most difficult stages is the sixth which is the determination of the factors shaping the production cost and their assessment. There are a lot of factors influencing the shaping of the production cost. They can be distinguished in two categories: 1) those that are related to the production conditions (production type; technological processes; level of specialization, cooperation, concentration; production automatization and robotization, etc.); 2) those that are related to the intended purposes and measures to stabilize or develop activity (improvement of labour organization, installation of advanced technologies, changes in production scope and range, improvement of working conditions, development of employees' competences, etc.). It should be noted that it is difficult to express the influence of most of the factors in monetary terms although there are no doubts about their impact. Therefore it is important to examine both the nature of the factors influence, and the reasons for the changes. Various sources of analyses not related to accounting are used for this purpose (material from meetings, sessions, commissions, conferences; employee surveys and sociological studies; technical documents; manufacturing works graphs; economic contracts; claims, etc.) and certain heuristic research methods (analogy, association, discussions in a group, expert evaluation, etc.).

In the seventh stage of the production cost analysis, the information from every stage is systematized and assessed in order to achieve the main aim of the analysis which is to determine the reserves and possibilities to reduce the production cost. Here, attention must be paid to the responsibility of departments of the company (responsibility centres) for certain costs. The results of the analysis have to be discussed in the company's management meetings, when making operational decisions on what are the costs and by what ways and measures they can be reduced.

The prepared methodology of the complex analysis of the production cost may be successfully applied in various manufacturing enterprises. 


\section{CONCLUSION}

1. The structural and dynamical analysis of Lithuanian business enterprises' expenditure and expenses from 2014 to 2018 revealed that in the last few years, Lithuanian business enterprises' expenditure was growing. For example, from 2014 to 2018, the expenditure increased by $26.18 \%$. However, the expenditure per company hardly changed and on average amounted to around 1 million euros a year. Expenditure structure analysis shows that the value of raw materials, materials, fuel, goods for resale consumed amount to the largest relative part of the total expenditure (in 2014 they amounted to $68.36 \%$ and in 2018 to $63.16 \%$ ). Wholesale and retail trade as well as manufacturing enterprises incur the highest expenditure. The largest share of expenditures incurred by the wholesale and retail trade enterprises consists of the value of goods for resale consumed. Value of raw materials, materials and fuel, value of services purchased, and personnel costs are the highest at manufacturing enterprises. In general, in 2018, these expenditures amounted to $38.98 \%$ of all the country's business enterprises' expenditures. It is a very significant share considering that the manufacturing enterprises amount only to $9.19 \%$ of all the business enterprises. From the analysis of the cost of sales according to the types of economic activity, it is clear that in absolute terms these expenses were the highest at wholesale and retail trade enterprises. Yet, from the assessment based on the cost of sales per one enterprise, it is clear that this indicator is much higher at manufacturing enterprises. In 2018, the average cost of sales per one wholesale and retail trade enterprise amounted to 1.40 million of euros whereas at manufacturing enterprises this indicator was 2.47 million of euros.

2. The manufacturing enterprises must pay the most attention to the analysis and assessment of expenditures since various expenditures are incurred during the production and they are larger than that of enterprises from other sectors; also the procedures to estimate the production cost are more complex. Respectively, the production cost analysis is more complicated in manufacturing enterprises thus it is necessary to carry it out in a consistent and comprehensive way. Only a consistent production cost study can reveal the cost reduction reserves and possibilities. The suggested methodology of the complex analysis of the production cost consists of the following stages: 1) analysis of the changes of the production cost volume; 2) analysis of the production cost composition and structure; 3) raw materials cost analysis; 4) labour cost analysis; 5) direct cost and overhead cost variances analysis; 6) analysis of the factors shaping the production cost; 7) discussion of the analysis results, their summarization, presentation of conclusions and suggestions.

3. It is recommend to carry out the specific actions at every stage of the production cost analysis which would ensure the high quality of the analysis results. In the first stage of the production cost analysis, it is necessary to compare the cost of the reporting period with the cost of the previous period and determine the size and causes for its increase or decrease. In the second stage, the particular attention should be paid for the analysis of the composition and structure of direct and indirect costs. During the third stage, the analysis of the supply of raw materials, analysis of condition of raw materials, and analysis of the raw materials usage in the manufacturing process have to be carried out; also, it is recommended to estimate raw materials receptivity ratio, raw materials productivity ratio, raw materials put in a good use ratio, and raw materials storage time (in days). In the fourth stage, firstly, the elements constituting the total payroll are studied; later, absolute and relative changes in the total payroll are estimated and the analysis of the total payroll according to the forms of remuneration is carried out; also, it is recommended to conduct the analysis of the total payroll according to the forms of remuneration, and the analysis of the basic and additional remuneration. During the fifth stage, the actual direct materials costs, direct labour costs and overhead costs are compared to the standard costs, the variances are estimated, and an analysis of the variances is carried out. During the sixth stage, it is recommended to identify factors related to the production conditions and factors related to the intended purposes and measures to stabilize or develop activity. In the seventh stage 
of the production cost analysis, the information from every stage is systematized and assessed in order to achieve the main aim of the analysis which is to determine the reserves and possibilities to reduce the production cost. The prepared methodology of the complex analysis of the production cost may be successfully applied in various manufacturing enterprises.

\section{REFERENCES}

9th Business Accounting Standard „Inventories“ (2018). The Authority of Audit, Accounting, Property Valuation and Insolvency Management. Retrieved April 20, 2020, from http://www.avnt.lt/assets/Veiklossritys/Apskaita/VAS/Priimti-standartai/9-VAS-isakymas-TAR-ikelimui.pdf.

Acién, F.G., Fernández, J.M., Magán, J.J. \& Molina, E. (2012). Production cost of a real microalgae production plant and strategies to reduce it. Biotechnology Advances, 30, 1344-1353, https://doi.org/10.1016/j.biotechadv.2012.02.005.

Aryasri, A.R. (2020). Managerial Economics and Financial Analysis. 2nd ed. McGrow Hill Education.

Bocharov, V.V. (2005). Komleksnij finansovij analiz. [Complex financial analysis]. Saint Petersburg: Piter.

Bozgulova N., Parmanova R., Abenova M., Ivanyuk T. \& Aryshev V. (2019). Calculation methods for cost management in the construction industry. Entrepreneurship and Sustainability Issues, 7(2). 1450-1461. http://doi.org/10.9770/jesi.2019.7.2(46).

Bragg, S. (2017). Financial Analysis: A Business Decision Guide. 3rd edition. Accounting Tools.

Budrionyte, R. \& Gaižauskas, L. (2018). Historical cost vs fair value in forest accounting: the case of Lithuania. Entrepreneurship and Sustainability Issues, 6(1), 60-76. http://doi.org/10.9770/jesi.2018.6.1(5)

Eddelani, O., El Idrissi, N. E. \& Monni, S. (2019). Territorialized forms of production in Morocco: provisional assessment for an own model in gestation. Insights into Regional Development, 1(1), 6-18. https://doi.org/10.9770/ird.2019.1.1(1)

Firescu, V. \& Branza, D. (2016). Cost volume profit, a managerial accounting technique. Scientific Bulletin - Economic Sciences, 15, Special Issue, 25-34. http://economic.upit.ro/repec/pdf/2016 33.pdf

Ghandour, G., F. (2017). The relationship between cost-volume-profit management and profitability in private organizations. International Journal of Advanced Engineering Research and Science, 4(4), p. 281-288. https://dx.doi.org/10.22161/ijaers.4.4.43.

Glembotskaya, G.T., Eremin, S.Yu. \& Chupandina, E.E. (2020). Scientific priorities and real prospects for cost optimization in formulation development. Entrepreneurship and Sustainability Issues, 7(3), 14841499. https://doi.org/10.9770/jesi.2020.7.3(4)

Gunarathe, N. \& Samudagre, D. (2018). Analysis of the cost structure: perspectives from the manufacturing companies in Sri Lanka. Asia-Pacific Management Accounting Journal, 13 (3), 197-223.

Hilkevics, S. \& Semakina, V. (2019). The classification and comparison of business ratios analysis methods. Insights into Regional Development, 1(1), 48-57. https://doi.org/10.9770/ird.2019.1.1(4)

Kidane, F. (2012). The role of cost analysis in managerial decision making: a review of literature. Asian Journal of Research in Banking and Finance, 2(3), 60-69.

Kovalev, V.V. (2004). Finansovij uchet $i$ analiz: konceptualnie osnovi [Financial accounting and analysis: a conceptual framework]. Moscow: Finance \& Statistics.

Le, O.T.T., Tran, P.T.T., Tran, T.V. \& Nguyen, C.V. (2020). Application of cost-volume-profit analysis in decisionmaking by public universities in Vietnam. Journal of Asian Finance, Economics and Business, 7(6), 305-316. https://doi.org/10.13106/jafeb.2020.vol7.no6.305.

Lujal, E. \& Iseni, E. (2018). Role of analysis CVP (Cost-Volume-Profit) as important indicator for planning and making decisions in the business environment. Proceedings of the 15th International Conference on Social Sciences, 1, 343-360. 13-14 July 2018. Leuven.

Mackevičius, J. \& Valkauskas, R. (2012). Methodic of complex analysis for the inventory. Science and Studies of Accounting and Finance: Problems and Perspectives, 1 (8), 142-147.

Mackevičius, J. (2007). Imonin veik.los analize: informacijos rinkimas, sisteminimas ir vertinimas. [Analysis of enterprises activity: collection, systematization and evaluation of information]. Vilnius: TEV. 
Mackevičius, J., Molienè, O. \& Poškaitė, D. (2007). Methodology of complex analysis of return on equity. Business: Theory and Practice, 8(2), 73-81. https://doi.org/10.3846/btp.2007.12.

Mackevičius, J., Molienè, O. \& Poškaitè, D. (2008). Methodology of complex analysis of return on sales. Economics, 81, 74-90. https://doi.org/10.15388/Ekon.2008.17646.

Mackevičius, J., Šneidere, R. \& Tamulevičienè, D. (2018). Complex analysis of company bankruptcy forecasting: theoretical insight. Proceedings of the scientific conference "Society. Integration. Education", VI, 319-329. May 25th - 26th, 2018. Rēzekne: Rēzeknes Tehnolog̣iju akadēmija. https://doi.org/10.17770/sie2018vol6.3425.

Mackevičius, J.; Subačienè, R. \& Senkus, K. (2012). Complex profitability analysis of fixed tangible assets. Bulletin of Taras Shevchenko National University of Kyiv, 17-21.

Mazzoni, F. 2020. Circular economy and eco-innovation in Italian industrial clusters. Best practices from Prato textile cluster. Insights into Regional Development, 2(3), 661-676. https://doi.org/10.9770/IRD.2020.2.3(4)

Novák, P. \& Popesko, B. (2014). Cost variability and cost behaviour in manufacturing enterprises. Economics and Sociology, 7(4), 89-103. doi: 10.14254/2071-789X.2014/7-4/6.

Novák, P., Dvorský, J., Popesko, B., \& Strouhal, J. (2017). Analysis of overhead cost behavior: case study on decisionmaking approach. Journal of International Studies, 10(1), 74-91. doi:10.14254/2071-8330.2017/10-1/5

Official Statistics Portal. Indicators database. Retrieved May, 10, 2020, from https://osp.stat.gov.lt/statistiniurodikliu-analize\#/.

Panfilova, E., Dzenzeliuk, N., Domnina, O., Morgunova, N. \& Zatsarinnaya, E. (2020). The impact of cost allocation on key decisions of supply chain participants. International Journal of Supply Chain Management, 9(1), 552-558. http://ojs.excelingtech.co.uk/index.php/IJSCM/article/view/4328

Petrenko, E., Pizikov, S., Mukaliyev, N. \& Mukazhan, A. (2018). Impact of production and transaction costs on companies' performance according assessments of experts. Entrepreneurship and Sustainability Issues, 6(1), 398410. http://doi.org/10.9770/jesi.2018.6.1(24).

Savitskaya, T.V. (2005). Metodika kompleksnovo analiza xoziajstvenoj dejatelnosti [Methodology of economic activity complex analysis]. Moscow: Infra-M.

Sheremet, A. (2002). Teorija ekonomicheskovo analiza [Theory of Economic Analysis]. Moscow: Infra-M.

Stoenoiu, C.E. \& Cristea, C. (2018). Comparative analysis for estimating production costs. MATEC Web of Conferences 184, Annual Session of Scientific Papers IMT OR ADEA, 184. https://doi.org/10.1051/matecconf/201818404004.

Tamulevičienè, D. \& Mackevičius, J. (2019). Methodology of complex analysis of tangible fixed assets. Entrepreneurship and sustainability issues, 7(2), 1341-1352. https://doi.org/doi:10.9770/jesi.2019.7.2(38).

Tamulevičienè, D. (2016). Methodology of complex analysis of companies' profitability. Entrepreneurship and Sustainability Issues, 4 (1), 53-63. https://doi.org/10.9770/jesi.2016.4.1(5).

Timmer M.P. (ed.) (2012). The world input - output database (WIOD): contents, sources and methods. WIOD Working Paper, 10, Retrieved May 13, 2020, from http://www.wiod.org/publications/source docs/WIOD sources.pdf

Valužis, K. (2000). Apskaitos sistema. [accounting system]. Vilnius: Viltis.

Wiener, J. (1962). The cost structure of the industrial enterprise: Pattern of analysis. Accounting review, 37, (3), 438-451.

Wilting H.C. \& Hanemaaijer A. (2014). Share of raw material costs in total production costs. PBL publication, 1506. The Hague, PBL Netherlands Environmental Assessment Agency.

Żwirbla, A. (2009). Two-dimensional variance analysis of direct cost. Theoretical Journal of Accounting, 52 (108), $133-158$.

Żwirbla, A. (2010). Model of variance analysis of direct labor costs. Theoretical Journal of Accounting, 55(111), 167-196. 